\title{
大地震時における消防隊の到着時間からみた道路閉塞情報収集の有効性 INFORMATION COLLECTION OF STREET BLOCKAGE AFTER A LARGE EARTHQUAKE FOR REDUCING ACCESS TIME OF FIRE FIGHTERS
}

\author{
大佛俊 泰*1, 廣川典昭*2, 沖 拓 弥*3 \\ Toshihiro OSARAGI, Noriaki HIROKAWA and Takuya OKI
}

\begin{abstract}
The previous studies presume that the use of emergency vehicles will be obstructed by collapsed buildings after a large earthquake. In this paper, we investigate a method for assisting fire fighters for their effective and efficient access to the locations of fires. More specifically, first, we construct a simulation model that describes the movement of fire engines under the condition of street-blockages caused by collapsed buildings. Next, using the proposed model, we attempt to evaluate the effects of street-blockage information collected by residents on improving the accessibility of fire engines. Finally, based on the simulation result, we demonstrate that the access time to the locations of fires can be effectively reduced by using the streetblockage information.
\end{abstract}

Keywords : large earthquake, fire fighter, accessibility, street-blockage, information collection, multi-agent simulation 大地震, 消防隊員, 到着時間, 道路閉塞, 情報収集, マルチェージェント・シミュレーション

\section{1.はじめに}

\section{(1) 研究の背景と目的}

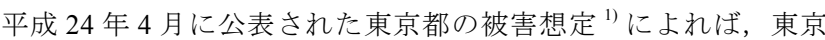
湾北部地震 (M7.3) 発生時には, 800 棟以上の建物から出火して 20 万棟以上の建物が焼失し，火災による死傷者は 2 万人以上にの ぼるとされている。被害を最小限にとどめるには，地域住民による 初期消火と，公設消防による迅速な消火活動が鍵となる。しかし， 木造住宅密集地域においては倒壊した建物の瓦碩により細街路が 閉塞し，消防活動に支障をきたす可能性が高い。首都直下地震発 生の切迫性を考えれば, 耐震化や不燃化の推進と平行して, 道路 閉塞の発生を前提とした消防活動戦略について検討しておくことの 必要性は高い。

大地震時の同時多発火災を対象とした消防活動に関しては, 多 くの優れた研究蓄積がある。例えば, 久貝・加藤の一連の研究 ${ }^{3)-7)}$ では, 消防車両の活動可能区域の大きさ等から, 市街地全体の道 路網の防災性能を評価する手法をパーコレーション理論に基づき 提案している。ただし，この手法は市街地整備の際の基準を得る ものであり, 発災直後の消防活動支援を対象とした研究ではない。
また, 田口ら ${ }^{8)}$ は, 119 番通報や駆けつけ通報を考慮した精緻な モデルを構築し，管轄を超えた広域的な消防力の運用を視野に， その切替え時期について出火件数をもとに検討している。中野・ 熊谷 ${ }^{9)}$ は, 発災初動時の火災を対象とした消火シミュレーション システム (FIMaS) を用いて, 水量の充足率（既存水量／必要水量） の視点から, 震災時に利用可能な水利の配備と水量について検討 している。さらに, 関澤ら ${ }^{10) \sim 44)}$ は, 延焼予測と消防力運用のシ ミュレーションシステムを構築し, 焼失低減率等の指標を用いて, 神奈川県や埼玉県等で多数のケーススタディを行っている。これ

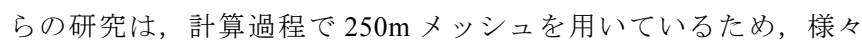
な地域に適用できるほか, 計算時間も比較的短く, 都道府県や関 東全域等の広域なシミュレーションにも適用できる点で優れてい る。しかし, 道路閉塞による消防隊の到着遅延や建物の耐震化, 建物の道路からのセットバックによる影響などを考慮したミクロ な分析を行うことは困難である。

一方, 災害情報に関する研究として, 近藤・目黒 ${ }^{15)}$ は災害情 報を蓄積・共有するだけでなく，時間的・空間的な災害状況理解 を支援することで，すべての人々に災害イメージを想起させ，実

本稿は文献32），33）をもとに新たに分析を加え加筆・修正したものである。

*1 東京工業大学大学院情報理工学研究科 教授・博士 (工学)

独立行政法人科学技術振興機構 CREST

*2 東京工業大学大学院情報理工学研究科 修士課程

独立行政法人科学技術振興機構 CREST

*3 東京工業大学大学院理工学研究科 助教 · 修士 (工学)

Prof., Graduate School of Information Science and Engineering, Tokyo Institute of Technology, Dr. Eng.

CREST, Japan Science and Technology Agency

Graduate Student, Graduate School of Information Science and Engineering, Tokyo Institute of Technology

CREST, Japan Science and Technology Agency

Assistant Prof., Graduate School of Science and Engineering, Tokyo Institute of Technology,

独立行政法人科学技術振興機構 CREST

M. Eng.

CREST, Japan Science and Technology Agency 
効性の高い防災対策の実現に貢献することを試みている。しか し, 震災前と復興期を主な対象としており, 発災直後の行動支援 のための災害情報の活用は対象としていない。また,杉井ら ${ }^{16)}$ は, 発災直後の情報収集方法について, 過去の調查結果をもとに分析 し，119 番通報や高所カメラ等の様々な情報収集方法の問題点を 指摘した上で，高所見張りを中心とした情報収集が最も有効であ ると述べている。しかし, 議論は定性的な範囲に留まっており, 災害情報収集の定量的な評価は行っていない。

以上の既往研究を踏まえ, 本稿では, 道路閉塞が消防隊の到着 遅延に及ぼす影響や道路閉塞情報を収集・活用することの効果に ついて, 現実の市街地を対象としたミクロな定量的分析を試みる。 具体的には, 発災直後の道路閉塞が消防活動（特に出火建物まで の消防隊の移動）に及ぼす影響を分析し，消防活動の支援策につい て検討する。まず，建物倒壊や道路閉塞などの物的被害を記述する モデル (物的被害モデル) を構築し, 次に, 消防水利の空間的配置 等を考慮した消防車両・消防隊の移動を記述するモデル（消防隊モ デル）を構築する。また，これらを統合して消防隊移動シミュレ ーションを実行し, 消防署から出火建物までの到着時間を評価指 標として, 閉塞のない場合 (平常時) と大地震発生時との比較分 析を行う。さらに, 地域住民による道路閉塞情報の収集行動（情 報収集モデル）をシミュレーションに組み込み，収集された閉塞 情報が消防隊の到着時間短縮に及ぼす効果について分析する。最 後に, 大地震発生時に消防活動を円滑に行うための初動行動支援 策について考察する。

\section{(2) 本稿の構成}

第 2 章では，地表面応答に基づく建物の倒壊や火災の発生，お よび, 道路閉塞といった物的被害のモデル化について述べる。次に, 消防隊が出火建物まで消防車両によって移動する行動のモデル化に ついて述べる。第 3 章では，本稿でのシミュレーション条件を整 理し, 分析対象地域（東京都世田谷区）の現状について分析する。

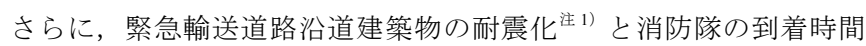
との関係について考察を行うと同時に，道路閉塞情報が消防隊の 到着時間の短縮に及ぼす有効性についてシミュレーション分析を もとに考察する。第 4 章では, 道路閉塞情報を収集する地域住民 の数と把握できる閉塞箇所の割合 (閉塞把握率) について考察する。 最後に, 閉塞把握率と消防隊の到着時間との関係について分析し, 地域住民が発災直後に道路閉塞情報の収集を行う効果について考察 する。

\section{2. シミュレーションモデルの概要}

\section{(1) 物的被害モデルの概要}

大地震がもたらす物的被害に関する研究は，建造物の物性に関 する研究成果の蓄積や過去に発生した震災の被害調査等に支えら れ，ますます精緻化されている。近年では, GIS 技術の進展に伴い, 建物 1 棟, 道路 1 本単位で被害推定が行えるミクロな物的被害モ デルも提案されている。本稿では, 利用可能なデータの制約やモデ ルの簡便性，適合性などを勘案し，以下に示すモデルを援用した。

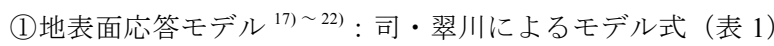
(2)建物倒壊モデル ${ }^{23), 24)}$ : 村尾・山崎によるモデル式注2) (3)道路閉塞モデル 25) 27) : 国土交通省によるモデル式注3)
(4)出火判定モデル 28), 29) : 東京消防庁による用途別出火率注4)

図1(a)に物的被害の推定手順を示してある。ここでは，地形・ 地盤分類の $250 \mathrm{~m}$ メッシュデータ（図 1(b)）や，平成 23 年土地 利用現況調查に基づく建物や道路に関寸る詳細なデータ（GIS デー タ）（図 1(c)）を用いた。

なお，本稿においては，消防隊の出火建物までの到着時間に注 目寸ることから，モデルの簡略化に努め，火災の延焼については考 慮しないこととする。また, 消防隊の到着時間を遅らせる要因とし て, 一般車両による渋滞なども考えられるが, 現時点で発災直後 の渋滞予測を精緻に行うことは困難であるため, 今後の課題とし た。

\section{（2）建物倒壊モデル}

既存の建物被害関数 ${ }^{23)}$, 24) を用いれば，実構造別・建築年代別・ 地表面最大速度別に倒壊確率を算出することができる。しかし，利 用可能な GIS データには，近年実施された耐震工事に関する情報 が含まれておらず，倒壊建物数が過大に推計される傾向にある。そ こで, 平成 20 年住宅・土地統計調査のデータから算出される建築 時期・構造・建て方別の耐震工事率（図 1(d)）を利用して, 耐震 工事を行った建物を推定し GIS データを更新した。ここでは耐震 工事済夕と推定された建物は，新耐震基準（建築時期が 1981 年以 降）と同等の耐震性能を有していると仮定した。

\section{(3) 消防隊モデル}

消防隊は火災発生の通報を受けた後, 消火活動に最も有利と考 えられる消防水利まで消防車両で向かい，消防水利からは消防隊 員がホースを持って出火建物へ向からという一連の行動をモデル 化した（図 2)。ただし，震災時には，水道管の破損等により消 火栓が利用できない可能性があることから，消防隊は消火栓以外 の消防水利（防火水槽）のみを用いるものとした。また，消火活 動に最も有利な消防水利を，本稿では，「現在位置から消防水利 までの直線距離と, 消防水利から火災建物までの直線距離の和が 最小となる消防水利」とした。通行可能道路や通行速度は, 消防 車両と消防隊員に分けて想定した（表 2)。

ここで，閉塞道路に関する情報を有していないケース（閉塞情 報なし）については，まず，す心゙ての道路が通行可能な状況であ ると想定して経路探索を行う。しかし，目的地へ向かう途中で閉 塞道路に遭遇した場合には, その位置から再度経路探索を行う（こ のとき，遭遇した閉塞道路はすべて記憶する)。ただし，設定した 消防水利に向かう際，計 3 回閉塞道路に遭遇した場合には，その 消防水利への到着は困難と判断し ${ }^{\text {注 5) }}$, その位置から出火建物の消 火に最も有利な別の消防水利一目的地を変更すると考えモデル化し た。一方, 出動前に道路閉塞情報を入手できるケースについては, 最初から閉塞箇所を避けた経路探索を行う。

\section{3. シミュレーションの実行と分析結果の考察}

\section{表 1 震源パラメーター覧}

\begin{tabular}{|c|c|c|c|}
\hline 名称 & 值 & 名称 & 值 \\
\hline 断層帯 & 東京湾北部 & \multirow{2}{*}{$\begin{array}{l}\text { モーメント } \\
\text { マグニチュード }\end{array}$} & \multirow{2}{*}{ 7. 3} \\
\hline 震源位置 & $35.3200^{\circ}, 1401400^{\circ}$ & & \\
\hline 上端深さ & $\begin{array}{c}\text { フィリピン海プレートの } \\
1 \mathrm{~km} \text { 上方 }\end{array}$ & 走向·傾斜 & $296^{\circ}$ \\
\hline 長さ・幅 & $63.64 \mathrm{~km}, \quad 31.82 \mathrm{~km}$ & 地震タイプ & プレート間 \\
\hline
\end{tabular}




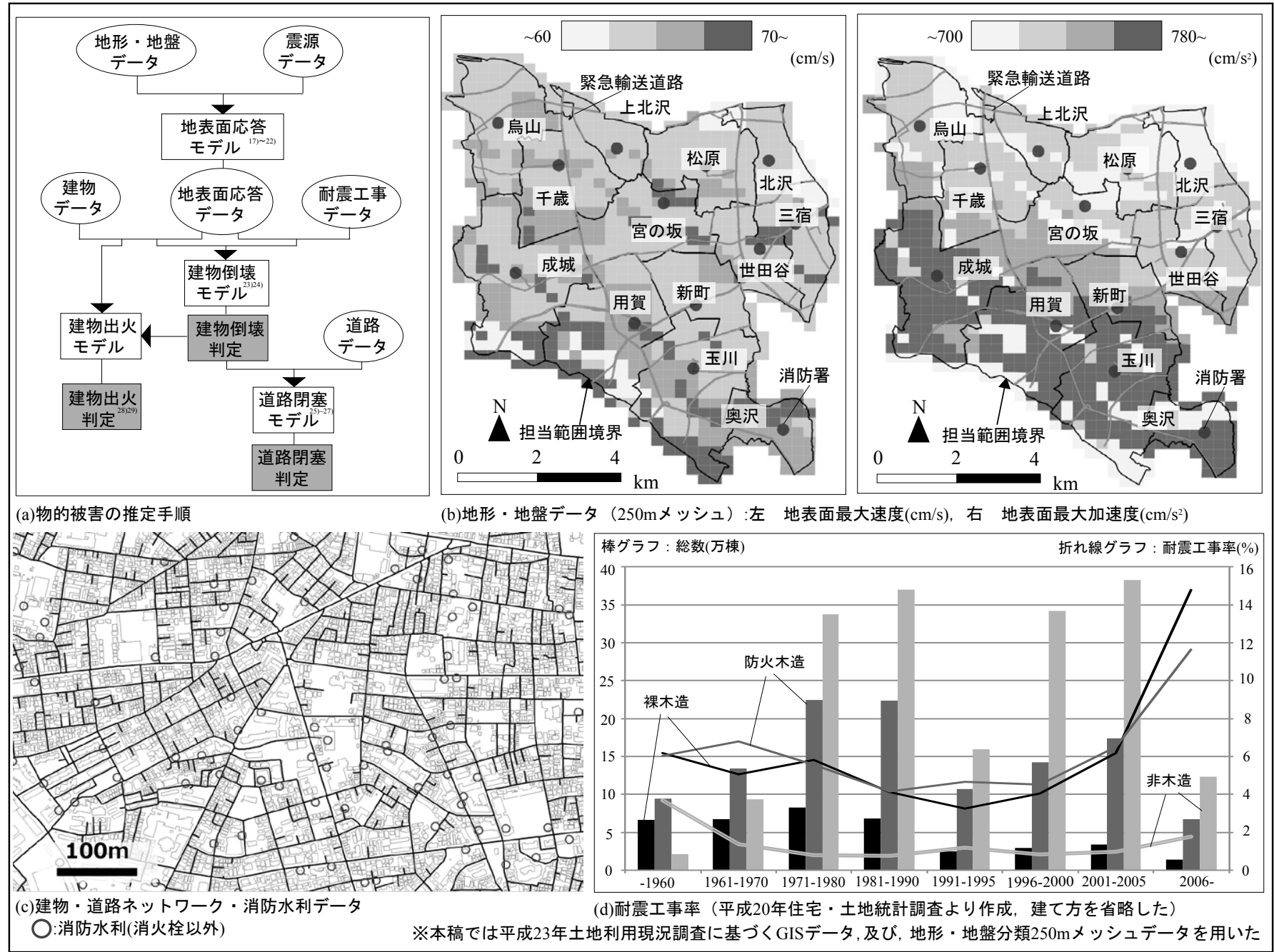

図 1 使用データと物的被害モデルの推定手順

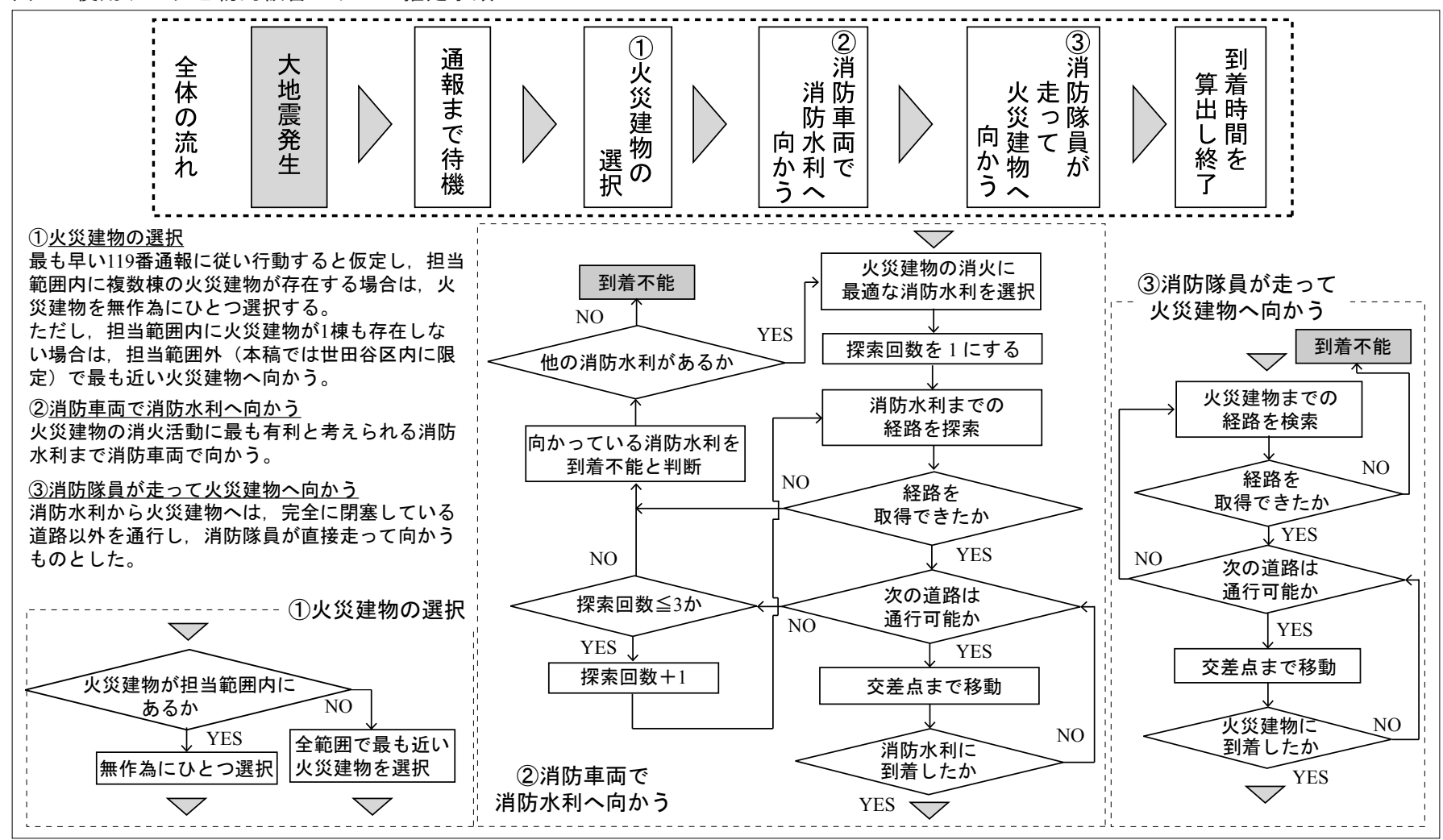

図 2 消防隊モデル 


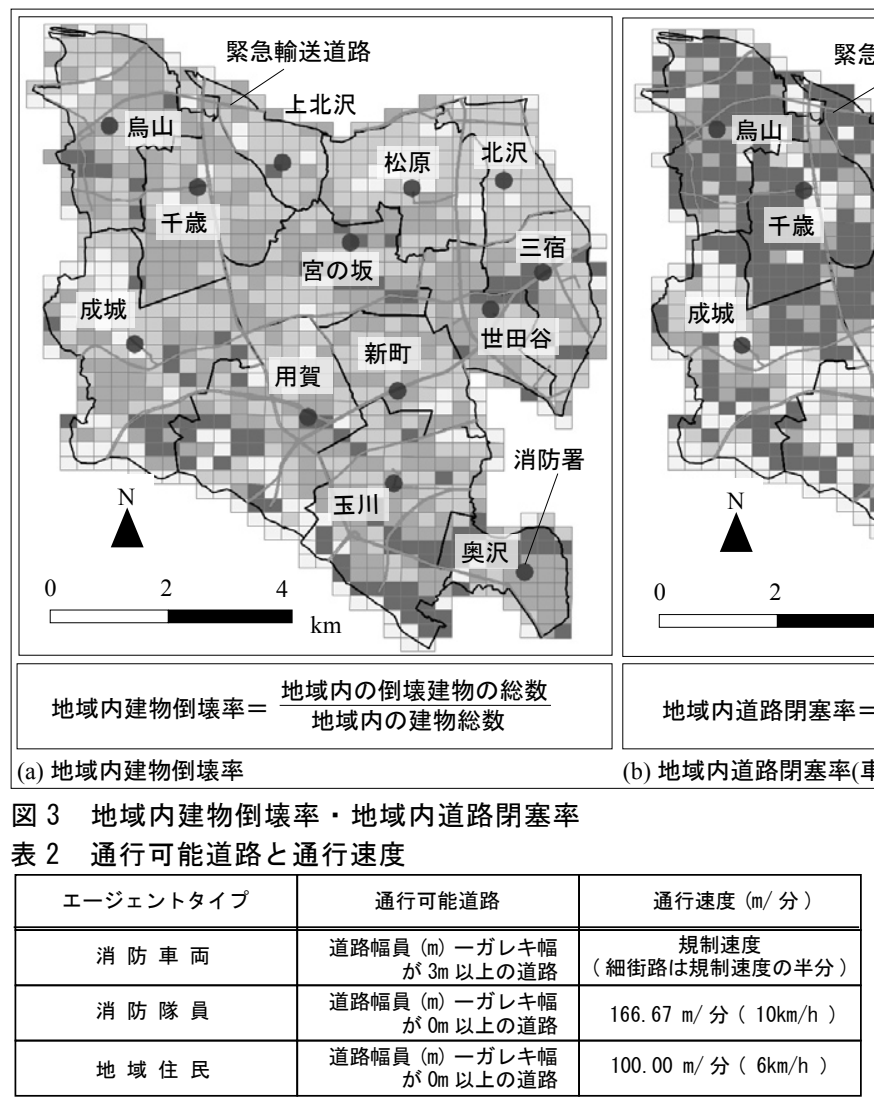

（1）シミュレーションの設定条件

典型的な木造住宅密集地域を有する東京都世田谷区を分析対 象地域とした。東京都による被害想定 ${ }^{1)} に$ 基づき, 被害が最も大 きくなるとされている東京湾北部地震（M7.3，冬季 18 時）の発 生を想定し, 消防隊移動シミュレーションを 300 回実行した。各 試行では, 異なる物的被害パターンを作成し, その各々について, (a) 道路閉塞のまったくないケース (閉塞なし), (b) 出動前に道路 閉塞情報を一切有していないケース (閉塞情報なし), (c) 緊急輸送 道路沿道建築物注 1) の耐震化が達成され, 緊急輸送道路は一切閉塞 しないケース (緊急輸送道路閉塞なし), (d) 道路閉塞は存在するが, すべての道路閉塞情報を把握しており, 閉塞道路を避けた経路探索 が可能であるケース (全閉塞把握) の 4 つのケースを想定し (表 3), 消防隊が出火建物に到着するまでの所要時間の平均值や最大值を求 めた。比較分析を容易にするため, 物的被害のパターンは各ケース (a) 〜 (d) で統一した。なお, 300 回の試行のうち, 出火建物周辺 の道路が激しく閉塞し, 出火建物に到着できないケースが全範囲 平均で約 6.5 回（約 $2.2 \%$ ）存在する。これらのケースは, 情報収 集の有無や方法の違いにかかわらず到着不能であり, 出火建物へ の到着時間が算出できないことから, 本稿の分析からは除外した。

\section{（2）建物倒壊率 · 道路閉塞率}

第 2 章の物的被害モデルを世田谷区に適用した結果を図 3 に示 してある。ここでは, 空間分布の様子を把握しやすくするため,

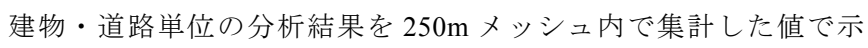
してある。地域内建物倒壊率はそれほど高くない地域であっても, 地域内道路閉塞率は高いことがわかる。これは, ひとつの道路に 複数の建物が関与しているためである。

（3）道路閉塞が消防隊到着時間に及ぼす影響

\begin{tabular}{|c|c|c|}
\hline$\sim 5 \%$ & & $10 \% \sim$ \\
\hline \multicolumn{3}{|c|}{ (c) 各担当範囲の集計量 } \\
\hline 担当名 & 地域内建物倒壊率 & 地域内道路閉塞率 \\
\hline 世田谷 & $7.83 \%$ & $18.75 \%$ \\
\hline 奥沢 & $9.68 \%$ & $18.15 \%$ \\
\hline 三宿 & $7.61 \%$ & $16.29 \%$ \\
\hline 宮の坂 & $7.76 \%$ & $15.20 \%$ \\
\hline 北沢 & $5.98 \%$ & $14.36 \%$ \\
\hline 千歳 & $7.30 \%$ & $12.98 \%$ \\
\hline 松原 & $6.11 \%$ & $12.45 \%$ \\
\hline 烏山 & $7.38 \%$ & $11.59 \%$ \\
\hline 上北沢 & $6.45 \%$ & $11.40 \%$ \\
\hline 新町 & $6.88 \%$ & $10.76 \%$ \\
\hline 玉川 & $8.93 \%$ & $10.71 \%$ \\
\hline 成城 & $7.11 \%$ & $8.83 \%$ \\
\hline 用賀 & $7.49 \%$ & $7.23 \%$ \\
\hline \multicolumn{3}{|c|}{$\begin{array}{l}\text { ※地域内建物倒壊率・地域内道路閉塞率は } \\
\text { 建物・道路単位で推定を行い, } 250 \mathrm{~m} \text { メッジで } \\
\text { 集計值を示してある。 } \\
\text { ※車両と人間のそれぞれについて } \\
\text { 通行可能判定を行った(表2)。 }\end{array}$} \\
\hline
\end{tabular}

表 3 シミュレーションの設定条件

\begin{tabular}{|l||c|c|c|}
\hline \multicolumn{1}{|c|}{ 条件 } & $\begin{array}{l}\text { 道路閉塞による } \\
\text { 通行不能道路 }\end{array}$ & $\begin{array}{c}\text { 緊急輸送道路 } \\
\text { 沿道建築物耐震化 }\end{array}$ & 道路閉塞情報の入手 \\
\hline \hline (a)閉塞なしし & なし & なし & なし \\
\hline (b)閉塞情報なし & あり & なし & なし \\
\hline $\begin{array}{c}\text { (c)緊急輸送道路 } \\
\text { 閉塞なし }\end{array}$ & あり & あり & なし \\
\hline (d)全閉塞把握 & あり & なし & あり \\
\hline
\end{tabular}

図 4 には各ケース (a)〜 (d) における, 消防車両の移動経路の例 を示してある。「閉塞情報なし」の場合（図4(b)), 消防署周辺の 閉塞道路の影響で, 消防車両は数回閉塞箇所に遭遇し, 到着時間に 大幅な遅延が発生している。世田谷区全体での分析結果をみると (図 5),「閉塞なし」と比較して,「閉塞情報なし」の平均到着時間 は 1.80 倍, 最大到着時間は 3.18 倍であり, 道路閉塞が到着時間 に及ぼす影響は無視できない。また，本稿では一般車両による渋滞 の影響を考慮していないことから, 実際には, 到着時間の遅延はよ り大きくなると考えられる。

\section{(4) 緊急輸送道路沿道建築物の耐震化効果}

緊急輸送道路注 1) を閉塞させないことの到着時間短縮に及ぼす 効果を図 5 に示してある。効果の大きい担当範囲では平均值で 約 30\%の短縮効果があることがわかる。しかし, 短縮効果には, 大きな地域差が存在する。これは, 緊急輸送道路を利用して移動で きる距離が地域によって大きく異なるためである。

\section{（5）道路閉塞情報による消防隊到着時間の短縮効果}

前節までのシミュレーションは, 消防隊の出動時に, どの道路が 閉塞しているか全くわからない状況を想定していた。しかし，ど こが閉塞しているかの情報が事前に入手できれば，閉塞箇所を避 けた経路探索が可能となり, 効率的に出火建物へ到着することが できる可能性がある。そこで，まずは極端なケースとして，出動 前に閉塞箇所がすべて把握できる場合（全閉塞把握）について検討 した。すなわち, 消防車両は通行可能幅員が $3 \mathrm{~m}$ 以上の経路のみ を用いて経路探索を行い, 到着時間が最短となる経路で移動する ことを仮定した（図4(d)）。

全範囲での集計量をみると（図 5), 「閉塞情報なし」と比較して, 平均到着時間は約 3 分の 2 に, 最大到着時間は約 3 分の 1 に短縮 

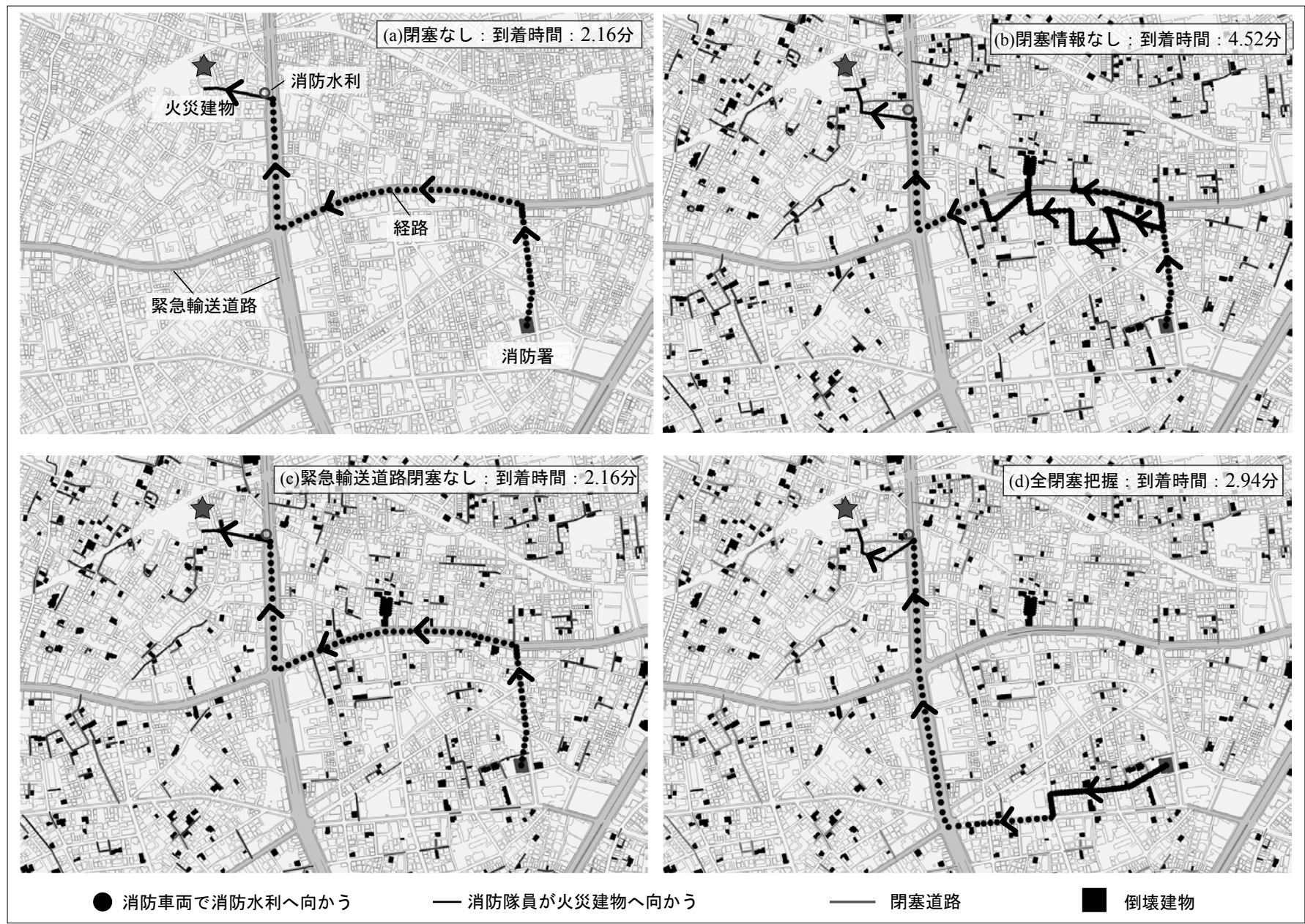

図 4 シミュレーションの実行例

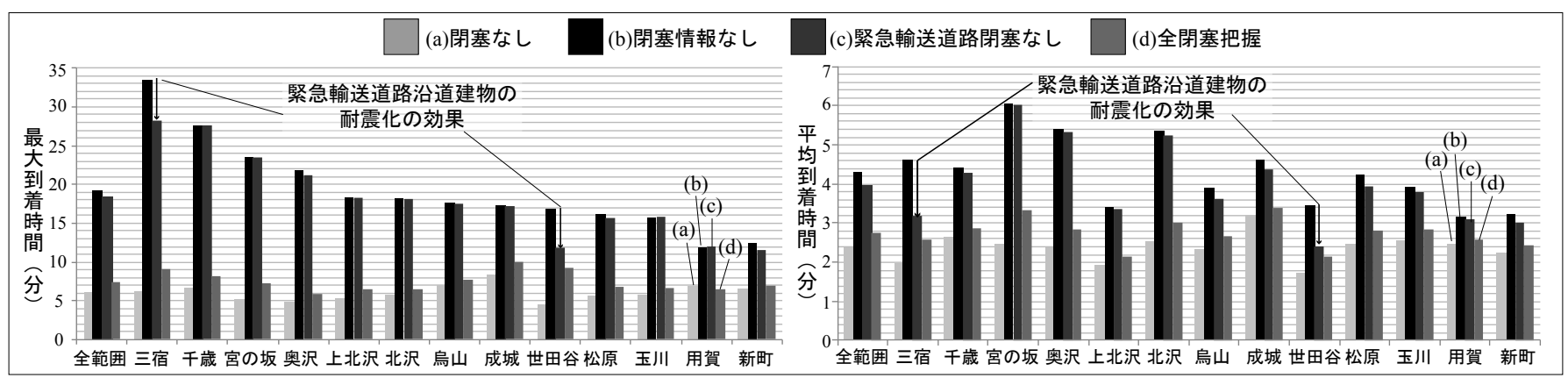

図 5 消防隊の最大到着時間と平均到着時間

されており，どちらも「閉塞なし」と同水準の到着時間であること がわかる。担当範囲別の分析結果を比較しても，地域に大きく依存 しないことがわかる。すなわち，道路閉塞に関する情報を活用寸れ ば, どのような地域においても, 消防隊到着時間の効果的な短縮 が期待される。

\section{4. 道路閉塞情報の収集が消防隊の到着時間短縮に及ぼす効果}

（1）道路閉塞情報収集の概要

災害情報を収集する方法には，地域住民の巡回による情報収集 の他にも, 高所カメラや高所見張, ヘリコプターによる上空から の情報収集等が考えられる。しかし, 高所カメラには災害情報同 定の問題, ヘリコプターを用いた方法には出動に要する時間の問 題など, 精度, 緊急性, 網羅性等の点で課題が残されている。一
方，兵庫県南部地震時に行われた消防隊員・消防団員の巡回によ る情報収集では, 特殊なハードウェアを必要とせず, 情報の精度 や信頼性が高いという利点が認められた。しかし，人員数の制約 や巡回時に閉じ込め者の救助を優先したことで, 情報収集に遅延 や偏りが生じる等, 情報収集活動が十分に機能しなかったことも 報告されている ${ }^{16)}$ 。

そこで, 本稿では, 発災直後から消防車両が出動するまでの短 い時間を積極的に活用して, 地域住民（防災ボランティア等）が 災害情報の収集を行うことで, 消防隊の到着時間の短縮に及ぼす 効果について考察する。具体的には, 地域住民の数や情報収集時 間と閉塞把握率の関係, さらに, 閉塞把握率と消防隊の到着時間 との関係について検討する。このとき, 大地震発生時においては, (1)火災は地震発生直後に発生するとは限らないこと, (2)火災の覚 

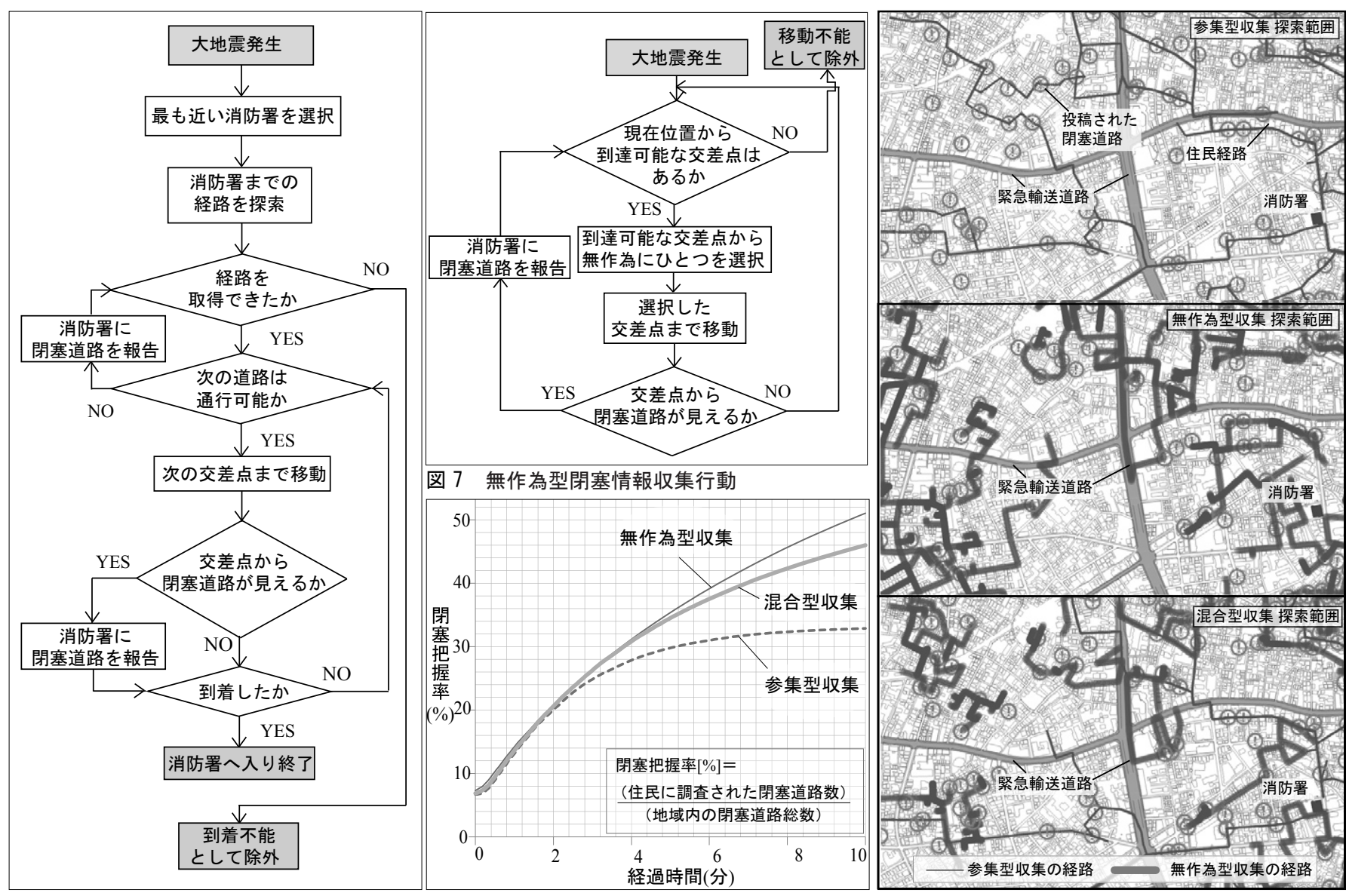

\section{図 6 参集型閉塞情報収集行動}

図 8 情報収集時間と閉塞把握率の関係

図 9 型別の情報収集行動の例（10 分後）

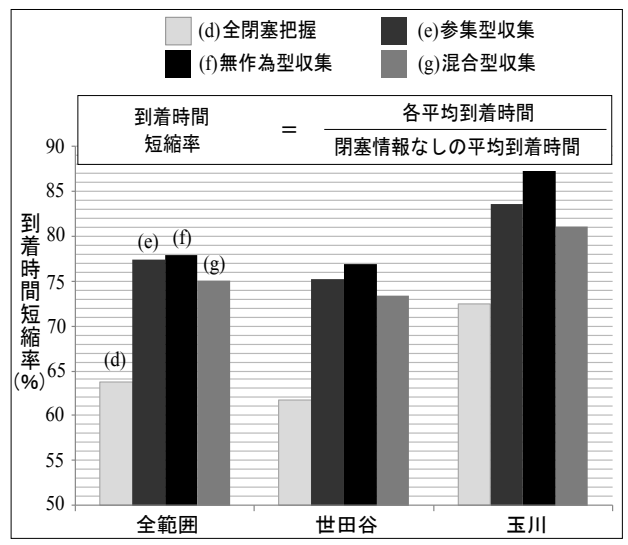

図 10 消防隊到着時間短縮率

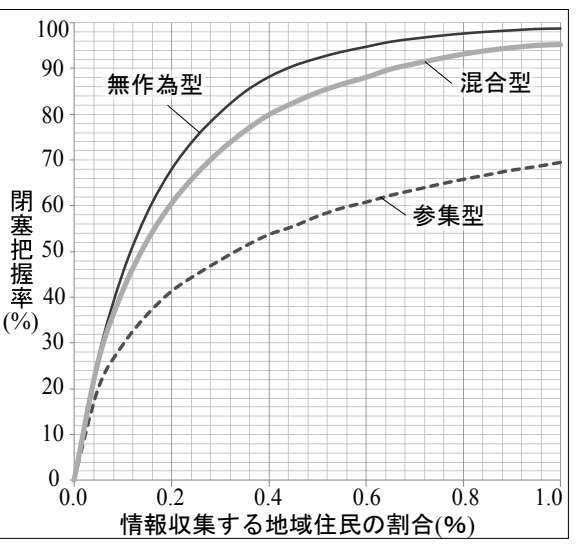

図 11 情報収集人員割合と閉塞把握率

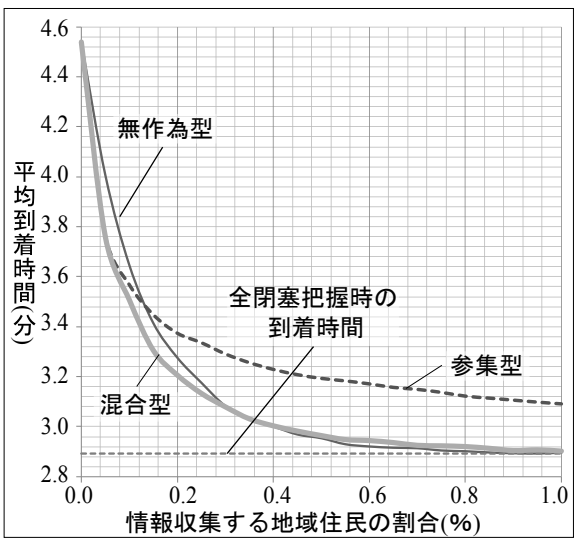

図 12 情報収集人員割合と消防隊到着時間
知にはある程度の時間を要すること，(3)限られた消防資源の配分 の観点から, 延焼危険度の高い地区（震災時出場区の上位地区） 以外の消火活動においては，一定時間（15 分間）待機する方針が とられていること ${ }^{30)}$ などを勘案し，本稿では，消防隊は発災 10 分後に出動すると仮定し, この 10 分間の災害情報収集の効果に ついて検討することとした。

\section{（2）参集型収集と無作為型収集}

地域住民の情報収集行動について 2 種類のモデルを想定した（図 6, 図 7)。それぞれ参集型収集, 無作為型収集と呼び, 詳細につ いては後述する。収集した閉塞情報は，携帯端末等を用いて，災 害情報収集・管理システムへ投稿され，全範囲の消防署で共有され るものと想定した。また，地域住民が通行可能な道路は，消防隊
員が消防水利から出火建物へ徒歩で向から場合と同様としたが，歩 行速度は消防隊員よりも幾分遅めに設定した（表 2 ）。

情報収集にあたる地域住民の数は，過去に事例がないため，ま ずは世田谷区における消防団員と同数（1056名：世田谷区の人 口售6) の約 $0.12 \%$ ）を仮定した ${ }^{31)}$ 。地域住民の発災時の居場所 は，世田谷区内の交差点上に一様乱数を用いてランダムに割り振 った。参集型収集は，最も近い消防署へ移動しながら閉塞情報を 収集・投稿することを想定した。ただし，消防署に到着した後は， 消防署内で待機し, 再度, 消防署を出て情報収集は行わないこと とした。無作為型収集は, 一定時間（10 分間）発災時の居場所 周辺を無作為に探索し (ランダムウォーク), 閉塞情報を収集・ 投稿する。ただし, 一度通行した道路は, 他の選択肢（道路）が 
ある限り通らないものとした。また，どの道路も通過したことが ある場合には, そのときの居場所（交差点）に接続する道路の中 から無作為に 1 つを選択して移動することとした。

\section{（3）情報収集方法（参集型収集 - 無作為型収集）の差異}

消防署一向かいながら情報収集を行う参集型収集は，消防署付 近での情報が重複することや，消防署に到着した後は情報収集を 行わないため, 閉塞把握率は $30 \%$ 程度に収斂する（図 8)。一方, 無作為に移動しながら情報収集を行う無作為型収集は, 発災後 10 分間で $50 \%$ 以上の閉塞把握率を示しており, 参集型収集よりも情 報収集能力は高い。これは，地域内で一様に情報収集を行うためで ある。しかし，消防隊員の到着時間に及ぼす短縮効果をみると（図 10)，参集型収集の方が優れていることがわかる。すなわち，同じ 時間 (10 分間), 同じ人数で閉塞情報の収集を行う場合, 参集型 収集の方が，より効率的に消防隊到着時間の短縮を図ることがで きることを示している。無作為型収集で得られる通行可能経路は 不連続になる傾向にあるのに対し，参集型収集で得られる通行可能 経路は，消防署から放射状に連続しているため，効率的な移動が可 能になるものと推察される（図 9)。また, 消防署付近の閉塞状況 がきめ細かく入手できることも影響している可能性がある。

次に，参集型収集と無作為型収集を半分ずつ混合して行う場合 (混合型収集) について検討する。混合型収集によれば，10 分間 の情報収集で $45 \%$ 以上の閉塞把握率を達成することができる（図 8)。また, 消防隊の到着時間を非常に効率的に短縮することがで きる（図 10）。混合型収集は，参集型収集と無作為型収集の欠点を 補いながら利点を生かし, 一層, 時間短縮効率を高められる可能性 を示唆しており興味深い。

\section{（4）情報収集者の数と閉塞把握率 - 到着時間の関係（混合型収集）}

以上の分析では，情報収集を行う地域住民の数を固定して検討し たが, 以下では, 地域住民の数を連続的に変化させ，閉塞把握率 と消防隊の到着時間との関係について検討する。シミュレーショ ンの結果を図 11, 図 12 に示してある。閉塞把握率・到着時間と もに，少人数による情報収集の際の変化量が非常に大きいことがわ かる。地域住民の数がわずかな場合には, 参集型収集の効率が高く, 消防隊の平均到着時間は急激に減少していることがわかる。一方, 地域住民の数がある程度多くなると，無作為型収集の方が効率が良 くなることがわかる。両者の特徵を兼敉備えた混合型収集によれ ば，地域人口の約 $0.5 \%$ の地域住民が情報収集すれば，閉塞把握率 は約 $85 \%$ となり，到着時間は約 4.5 分から約 3.0 分（約 67\%）に 短縮することができる。地域住民の数が増すにつれて, 閉塞把握率 は理論上の上限值 $(100 \%)$ 几，また，到着時間は下限値（全閉塞 把握時の到着時間) 一向けて指数関数的に漸近することがわかる。 寸なわち，たとえ少人数であっても，発災直後に閉塞情報の収集 にあたれば大幅な到着時間の短縮を図ることが可能であることを 示している。

\section{5. まとめ}

本稿では, 大地震時の物的被害（道路閉塞）の下での消防隊の行 動を記述する「消防隊移動シミュレーションモデル」を構築し，道 路閉塞が消防隊の到着時間に及ぼす影響について定量的に分析し た。また，地域住民による道路閉塞情報の収集が消防隊の到着時
間の短縮に及ぼす効果を検証した。具体的には，大地震時の物的被 害状況を建物・道路単位で精緻に記述し，これに消防隊の行動モデ ルを組み込むことで，消防隊の到着時間を定量的に評価すること のできるシミュレーションモデルを開発した。次にこのシミュ レーションモデルを用いて, 冬季 18 時に東京湾北部地震（M7.3） が発生した場合を想定したシミュレーションを実行し，到着時間 は平常時の約 2 倍近くになることを示した。また, 緊急輸送道路 沿道建築物の耐震化が，消防隊の到着時間短縮に貢献する程度を定 量的に評価した。さらに，情報収集を行う地域住民の数と到着時間 との関係について分析し，地域人口の約 $0.5 \%$ のが 10 分間情報 収集を行えば，約 $85 \%$ の道路閉塞情報が収集でき，理論上の下限 值付近まで到着時間を短縮できる可能性を示した。

ただし，本稿ではモデルの簡略化のため，一般車両による道路 渋滞や電柱やブロック塀等による道路閉塞の可能性については考慮 していない。これらの要因をモデルに組み込むことは，今後の課題 である。また，火災延焼についても考慮していない。実際には，延 焼方向や速度を考慮して消火活動に適した消防水利を選定し，消防 隊は移動することになる。さらに，消火栓は機能しないことを想定 して, 防火水槽等の利用を前提としたが, 断水の程度によっては, 消火栓を利用した方が効率的な消火活動が行える可能性がある。今 後は, 消防水利の位置や利用可能性, さらに, 火災の延焼過程や消 防団の初期消火などをモデルに組み込み, より精緻なシミュレー ション分析を実施する予定である。

建築物の不燃化や耐震化は, 災害に強い街づくりの根幹をなす ものであり, 今後も引き続き推進することが必要である。しかし， 大地震発生の切迫性を考えれば, 時間を要するハード面での整備 のみならず，比較的短時間で実現可能なソフト面での減災手法に ついても同時に検討しておくことの必要性は高い。本稿では，発 災直後における消防隊の初動対応を效率的・効果的に支援する視 点から, 道路閉塞情報を迅速に収集し，それを活用することの効 果について分析した。この他にも, 発災直後の災害情報を減災に 活用する応用事例は多数考えられる。筆者らは，本稿で想定した 発災直後の災害情報収集・投稿システムの構築に着手しており, その実証性については稿を改め報告したい。

\section{謝辞}

本研究を行うにあたり，東京消防庁の関係者各位より消防水利の データ提供と貴重なコメントを頂戴した。ここに記して謝意を表し ます。

注

注 1) 東京都は, 警察機関や消防機関を連絡する重要道路等の被害を軽減 することを目的として, 平成 23 年 3 月に「東京における緊急輸送道路 沿道建築物の耐震化を推進する条例」 ${ }^{2)}$ を公布し, 平成 24 年 4 月から は耐震診断の実施を義務化している。緊急輸送道路とは, 地震発生直 後からの緊急輸送を円滑に行うために東京都が指定した重要道路であ る。例えば, 応急対策の中枢を担う都本庁舎や空港等を連絡する路線, 警察, 消防等の初動対応機関を連絡する路線等が含まれ, 世田谷区では, 環状 $7 \cdot 8$ 号線や, 甲州街道等が指定されている。

注 2) 兵庫県南部地震時の被害データをもとに構築されたモデルであり, 建 築年代, 実構造種（木造・ RC 造・ $\mathrm{S}$ 造・軽量 $\mathrm{S}$ 造）, PGV（地表面最 大速度）に基づき, 建物の全壊確率等を算出できる。本稿では，これに 耐震工事の効果を組み込み，更なる精緻化を行った。 
注 3) 家田ら ${ }^{26)}$, 27) は兵庫県南部地震時の被害データに基づき, 町丁目ごと に集計されたパラメータ（木造率，全壊率，平均階層等）を用いて，道 路 1 本単位での閉塞確率を推定するモデルを構築した。国土交通省に よるリンク閉塞モデルは，この家田らによるモデルを，町丁目ごとで はなく, 道路 1 本の沿道建築物群に適用したモデルである。家田らが 推定したものは, 「道路縁からのガレキ幅」であり, 国土交通省の推定寸 るのは, 「建物前面からのガレキ幅二道路縁からのガレキ幅十セットバッ ク距離」である。この差を考慮し, 地域内の平均セットバック距離 $(1.26 \mathrm{~m})$ を足しあわせている。

注 4) 東京消防庁による建物用途別の出火率，及び，初期消火率を用いた。 このモデルは, 出火機構の分析, 振動実験, 兵庫県南部地震の精査に基 づき構築されている。入力パラメータは, 建物用途, 時間带 (季節・昼夜), 計測震度である。

注 5) 火災建物の周辺（3 口放水可能なエリア内）には, 複数の消防水利が 存在する。道路閉塞のある震災時にひとつの消防水利への到着に固執し 過ぎると, 到着時間が余計にかかってしまうことを予備実験で確認した。 平均再探索回数が 3 回を超えると到着時間の増大が認められたことを踏 まえ, 3 回閉塞道路に遭遇し，再探索を余儀なくされた時点で，その消防 水利への到着は困難と判断することとした。

注 6) 世田谷区の人口は, 平成 22 年国勢調查のデータに基づき, 87 万 7138 名とした。

\section{参考文献}

1) 東京都：首都直下地震等による東京の被害想定, http://www.bousai.metro tokyo.jp/japanese/tmg/assumption.html，2012.4 (2014.3.23 参照)

2) 東京都：東京における緊急輸送道路沿道建築物の耐震化を推進する条例, http://www.taishin.metro.tokyo.jp/tokyo/ordinance.html (2014.6.1 参照)

3) 久貝壽之・加藤孝明：道路閉塞からみた道路網防災性能の構造の解明, パーコレーション理論に基づいた地区レベル道路網の防災性能評価に 関する基礎研究その 4, 日本建築学会計画系論文集, No.615, pp.113$120,2007.5$

4) 久貝壽之・加藤孝明：地域レベルの領域から道路網防災性能上脆弱な 地区を抽出する評価手法の確立，パーコレーション理論に基づいた地 区レベル道路網の防災性能評価に関する基礎研究その 3 , 日本建築学 会計画系論文集, No.600, pp.105-112，2006.2

5) 久貝壽之・加藤孝明：通行可能確率分布を考慮した道路網の防災性能 評価手法の構築，パーコレーション理論に基づいた地区レベル道路網 の防災性能評価に関する基礎研究 その 2, 日本建築学会計画系論文集, No.593, pp.139-144, 2005.7

6) 久貝壽之・加藤孝明・小出治：パーコレーション理論に基づいた地区 レベル道路網の防災性能評価に関する基礎研究, 日本建築学会計画系 論文集, No.549, pp.231-237, 2001.11

7) 久貝壽之・加藤孝明・ヤルコン・ユスフ・小出治：道路閉塞からみた 地区レベル街路網の防災性能評価手法の提案, 地域安全学会論文集, No.1, pp.25-34, 1999.11

8) 田口元寿・糸井川栄一・熊谷良雄：主と直下地震時における火災被 害リスク低減雄ための戦略的な消防力運用に関寸る研究一消防力運 用方法の切替え時期と被害軽減効果の分析一, 地域安全学会論文集, No.10, pp.113-123, 2008.11

9) 中野孝雄・熊谷良雄：消防活動情報管理システムを活用した震災時利 用可能水利の評価, 日本火災学会論文集, Vol.51, No.1, pp.45-53, 2001.7

10) 関澤愛 ・佐々木克憲・杉井完治・山瀬敏郎・座間信作・遠藤真 : 震災 時における消防部隊の初期出場方式の違いによる延焼抑制効果の比較 分析, 地域安全学会梗概集, No.25, pp.5-6, 2009.11

11) 関澤愛・佐々木克憲・山瀬敏郎・座間信作・遠藤真・岡部弘志：消防 力最適運用支援システムを用いた市街地の地震火災リスク評価, 地域 安全学会梗概集, No.23, pp.1-4, 2008.11
12) 関沢愛 ·遠藤真・座間信作 ・ 山瀬敏郎・篠原秀明・佐々木克憲 ・ 川村 聡：同時多発火災に対する初動時の最適消防力運用効果の評価 : 最適 消防力運用支援情報システムを用いたケーススタディ, 地域安全学会 梗概集，No.13，pp.3-6, 2003.11

13) 関沢愛 ・ 遠藤真・座間信作・山瀬敏郎・篠原秀明・佐々木克憲 : 最適 消防力運用に資する消防活動支援情報の出力について，地域安全学会 梗概集，No.12，pp.71-74，2002.11

14) 関沢愛 ・ 高梨健一 ・遠藤真 ・座間信作 ・ 山瀬敏郎・篠原秀明・佐々木 克憲：リアルタイム延焼予測に基づく消防活動支援情報の出力システ 厶, 地域安全学会梗概集, No.11, pp.117-120, 2001.11

15) 近藤伸也・目黒公郎: 実効性の高い防災対策を実現できる災害情報デー タベースの構築, 地域安全学会論文集, No.4, p.p.261-266, 2002.11

16) 杉井完治・関沢愛 ・ 岡部弘志・遠藤真・座間信作・新井場公徳 : 震災 直後期における消防機関による実効性のある災害情報収集体制構築の 必要性, 地域安全学会論文集, No.10, pp.89-96, 2008.11

17) 若松加寿江・松岡昌志 : 地形・地盤分類 $250 \mathrm{~m}$ メッシュマップ全国版の 構築, 日本地震工学会大会－2008 梗概集, pp.222-223, 2008.11

18) 藤本一雄・翠川三郎：日本全国を対象とした国土数值情報に基づく地 盤の平均 $\mathrm{S}$ 波速度分布の推定, 日本地震工学会論文集, Vol.3, No.3, pp.13-27, 2003.7

19) 松岡昌志・若松加寿江 : 地形・地盤分類 $250 \mathrm{~m}$ メッシュマップ全国版に 基づく地盤のゆれやすさデータ, 産業技術総合研究所, 知的財産管理番 号 H20PRO-936，2008

20) 松岡昌志・翠川三郎：国土数值情報とサイスミックマイクロゾーニング, No.22 回地盤震動シンポジウム資料集, 日本建築学会, pp.23-24, 1994

21) 藤本一雄・翠川三郎：近接観測点ペアの強震観測記録に基づく地盤増幅 度と地盤の平均 $\mathrm{S}$ 波速度の関係, 日本地震工学会論文集, Vol.6, No.1, pp.11-12, 2006

22) 司宏俊, 翠川三郎：断層タイプ及び地盤条件を考慮した最大加速度・最 大速度の距離減衰式, 日本建築学会構造系論文集, No.523, pp.63-70, 1999.9

23) 村尾修・山崎文雄: 自治体の被害調査結果に基づく兵庫県南部地震 の建物被害関数, 日本建築学会構造系論文集, No.527, pp.189-196, 2000.1

24) 村尾修・山崎文雄：兵庫県南部地震における建物被害の自治体による 調査法の比較検討，日本建築学会計画系論文報告集，No.515，pp.187194, 1999.1

25) 国土交通省：まちづくりにおける防災評価・対策技術の開発，国土交通 省総合技術開発プロジェクト，2003.3.

26) 家田仁・望月拓郎・上西周子：地震時に建築物の倒壊等によって生じる街 路閉塞の危険度評価法，国際交通安全学会誌，Vol.23，No.3，pp.138-145， 1998.2

27) 家田仁・望月拓郎・上西周子：街路閉塞現象による機能的障害と地区の 危険度評価法, 土木計画学研究委員会 阪神 - 淡路大震災調査研究論文集, pp.433-440, 1997.9

28) 東京消防庁 : 直下の地震を踏まえた新たな出火要因及び延焼性状の解明 と対策, 火災予防審議会答申, 1997.3

29) 東京消防庁: 地震時における人口密集地域の災害危険要因の解明と消防 対策について，火災予防審議会答申，2005.3

30）東京消防庁：地震火災による人的被害の軽減方策，火災予防審議会答申， 2014.3

31) 総務省：あなたの街の消防団, http://www.fdma.go.jp/syobodan/search/13.html (2014.6.1 参照)

32) 廣川典昭・大佛俊泰・沖拓弥：大地震時の道路閉塞が緊急車両到着時間 に及ぼす影響, 日本建築学会大会学術講演梗概集, E-1, pp.121-122, 2013

33) 廣川典昭・大佛俊泰・沖拓弥 : 大地震時における道路閉塞情報の獲得が 緊急車両到着時間短縮に及ぼす影響, 地理情報システム学会講演論文集, Vol.22, CD-ROM, 2013.10 


\title{
INFORMATION COLLECTION OF STREET BLOCKAGE AFTER A LARGE EARTHQUAKE FOR REDUCING ACCESS TIME OF FIRE FIGHTERS
}

\author{
Toshihiro OSARAGI ${ }^{* 1}$, Noriaki HIROKAWA*2 and Takuya OKI ${ }^{* 3}$ \\ ${ }^{* 1}$ Prof., Graduate School of Information Science and Engineering, Tokyo Institute of Technology, Dr. Eng. \\ CREST, Japan Science and Technology Agency \\ $* 2$ Graduate Student, Graduate School of Information Science and Engineering, Tokyo Institute of Technology \\ CREST, Japan Science and Technology Agency \\ ${ }^{*} 3$ Assistant Prof., Graduate School of Science and Engineering, Tokyo Institute of Technology, M. Eng. \\ CREST, Japan Science and Technology Agency
}

The damage estimation, which was conducted by Tokyo Metropolitan Government in 2012, reports that 200 thousand or more buildings will be burned down and 20 thousand or more people will be killed or injured by fires in the Tokyo-epicenter major earthquake. In order to decrease the damage of fire-spreading, it is highly important that fire fighting activities are performed immediately after outbreaks of fires. Although buildings along main streets have been gradually converted into quake-resistant and fireproofing, many narrow streets still remain in high-density wooden residential areas. Therefore, the previous studies presume that the use of emergency vehicles will be obstructed by collapsed buildings after a devastating earthquake. We need not only to promote improvement of buildings toward quakeresistant and fireproofing, but also to consider other methods for disaster mitigation because we are facing emergent high risk of a major earthquake.

In this paper, we investigate a method for assisting fire fighters for their effective and efficient access to the locations of fires. More specifically, first, we construct a simulation model that describes the movement of fire fighters under the condition of streetblockages caused by collapsed buildings. Next, using the proposed model, we estimate the access time of fire fighters moving from fire stations to the locations of fires, for the following conditions; (1) no streets are blocked, (2) streets are blocked according to the property damage simulation results, (3) all the Urgent Transportation Roads are not blocked while other streets are blocked according to the property damage simulation results, (4) streets are blocked, but the locations of street-blockage are known. The simulation result shows that the average access time to the locations of fires will increase to twice time in the condition of street-blockages, with comparing to the no street-blockages. Also, it shows that the mean access time to the location of fires can be reduced to the same level as no streetblockages, when we know the locations of street-blockages. Namely, collecting information about street-blockage in advance may work as an effective strategy to improve the accessibility of fire fighters.

Next, we attempt to evaluate the effects of street-blockage the information collected by residents for improving the accessibility of fire fighters. We construct a model which describes information collection behavior of residents, and evaluate the means for collecting the street-blockage information, assuming the following strategies; (1) residents collect information by moving randomly, (2) residents collect the information by moving toward fire stations. Based on the result of the simulation, we demonstrate that the access time to the locations of fires can be effectively reduced by using the street-blockage information collected by residents. Although residents moving to the fire stations collect less information comparing to the random walking residents, their information have higher effects on shortening the access time of fire fighters. Also, the simulation result shows that it is possible to reduce access time to the same level as no street blockages in case that around 0.5 percentages of residents participate in collecting information of street-blockages.

（2014年 8 月 8 日原稿受理，2014年11月19日採用決定） 